\title{
IN SEARCH OF PARADISE
}





\section{IN SEARCH OF PARADISE}

Middle-Class Living in a Chinese Metropolis

\section{Li Zhang}

\section{CORNELL UNIVERSITY PRESS}

Ithaca and London

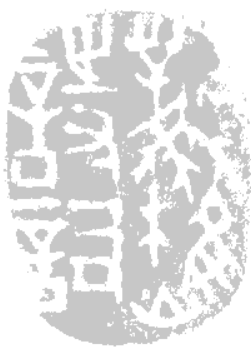




\section{Copyright ( 2010 by Cornell University}

All rights reserved. Except for brief quotations in a review, this book, or parts thereof, must not be reproduced in any form without permission in writing from the publisher. For information, address Cornell University Press, Sage House, 512 East State Street, Ithaca, New York 14850.

First published 2010 by Cornell University Press

First printing, Cornell Paperbacks, 2010

Printed in the United States of America

\section{Library of Congress Cataloging-in-Publication Data}

\section{Zhang, Li, 1965 May-}

In search of paradise : middle-class living in a Chinese metropolis /

Li Zhang.

p. $\mathrm{cm}$.

Includes bibliographical references and index.

ISBN 978-0-8014-4833-1 (cloth : alk. paper) -

ISBN 978-0-8014-7562-7 (pbk. : alk. paper)

1. Housing-China-Kunming Shi. 2. Real estate business-

China-Kunming Shi. 3. Middle class-China-Kunming Shi.

4. Privatization-China-Kunming Shi. 5. Land use-ChinaKunming Shi. 6. City planning-China-Kunming Shi. 7. Kunming Shi (China)-Geography. I. Title.

HD7368.K86Z43 2010

305.5'5095135-dc22 2009041332

Cornell University Press strives to use environmentally responsible suppliers and materials to the fullest extent possible in the publishing of its books. Such materials include vegetable-based, low-VOC inks and acid-free papers that are recycled, totally chlorine-free, or partly composed of nonwood fibers. For further information, visit our website at www.cornellpress.cornell.edu.

$\begin{array}{lllllllllll}\text { Cloth printing } & 10 & 9 & 8 & 7 & 6 & 5 & 4 & 3 & 2 & 1\end{array}$

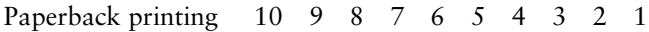


For Emily, Mark, and my father 
